ISSN: 1576-0162

DOI: http://dx.doi.org/10.33776/rem.v0i54.3826

\title{
Evolution of Regional InCOME Disparities IN LARGE EUROPEAN ECONOMIES
}

EVOLUCIÓN DE LAS DISPARIDADES REGIONALES DE INGRESOS EN GRANDES ECONOMIIAS EUROPEAS

Małgorzata Kokocińska University of Zielona Góra m.kokocinska@wez.uz.zgora.pl

Marcin Puziak Poznan University of Economics And Business marcin.puziak@gmail.com

Recibido: abril 2019; aceptado enero 2020

\section{ABSTRACT}

Growing income disparities, affecting developing and developed countries alike, are a fact and, at the same time, one of the greatest economic challenges of modern times. Empirical studies in various areas usually compare countries using the Gini coefficient or the relationship between external and internal convergence. To a lesser extent, those analyses concern the long-term formation of the level of regional inequalities and the impact of major political or economic events on their course. The main objective of this work is to examine the direction of changes in income distribution in large European economies at NUTS2 level in 2000-2015. That period was marked by the occurrence of two non-standard events: the largest enlargement of the European Union to date and 2008 financial crisis, which, regardless of their positive or negative nature, put the studied countries in a new economic situation on each occasion. Therefore, the question arises whether those tipping points exerted an influence on the distribution of income in large European economies such as Germany, United Kingdom, France, Italy, Spain, and Poland. The results of the study indicate various directions of the changes in regional income disparities over the researched period.

Keywords: Income Inequalities; Economic Growth; Regional Analysis; Large European Economies; 2008 Financial Crisis; Cohesion Policy. 


\section{RESUMEN}

Las crecientes disparidades de ingresos, que afectan tanto a los paîses en desarrollo como a los desarrollados, son un hecho y, al mismo tiempo, uno de los mayores desafíos económicos de los tiempos modernos. Los estudios empíricos en diversas áreas usualmente comparan países usando el coeficiente de Cini o la relaciōn entre convergencia externa e interna. En menor medida, esos análisis se refieren a la formación a largo plazo del nivel de desigualdades regionales y el impacto de los principales acontecimientos políticos o económicos en su curso. El objetivo principal de este trabajo es examinar la dirección de los cambios en la distribución del ingreso en las grandes economías europeas a nivel NUTS2 en 2000-2015. Ese período estuvo marcado por la ocurrencia de dos eventos no estándar: la mayor ampliación de la Uniōn Europea hasta la fecha y la crisis financiera de 2008, que, independientemente de su naturaleza positiva o negativa, coloca a los países estudiados en una nueva situaciōn económica en cada ocasiōn. Por lo tanto, surge la pregunta de si esos puntos de inflexión influyeron en la distribuciōn del ingreso en las grandes economías europeas como Alemania, Reino Unido, Francia, Italia, España y Polonia. Los resultados del estudio indican varias direcciones de los cambios en las disparidades regionales de ingresos durante el período investigado.

Palabras clave: Desigualdades de ingresos; Crecimiento económico; Análisis regional; Grandes economías europeas; Crisis financiera 2008; política de cohesiōn.

Clasificación JEL / JEL classification: E24; O11; O47; O52; R11; R12; R58. 


\section{INTRODUCTION}

The division into the rich and the poor is not only a growing concern for global social balance, but also causes disruptions within developed economies. Relevant literature points to many negative effects and sources of such inequalities. Those most frequently mentioned include lack of economic mobility and opportunities, lack of macroeconomic stability, and low economic growth (Dabla-Norris, Kochhar, Suphaphiphat, Ricka, \& Tsounta, 2015; OECD, 2014). The negative effects of growing disparities also include diminishing chances for people with low income to stay healthy and to accumulate physical and human capital (Galor \& Moav, 2004).

Moreover, some publications indicate a clear correlation between the level of inequality and such phenomena as life expectancy, literacy and mathematical skills, infant mortality, murder, prison population, teenage motherhood, confidence, obesity, mental illness (including addictions), and social mobility (Wilkinson \& Pickett, 2009).

As for strictly economic effects of the growing stratification, increasing likelihood of a financial crisis needs to be mentioned in the first place. Research shows that periods of deep economic divide are related to events such as the recent financial crisis, because they intensify indebtedness, trigger higher housing market leverage, and enable lobbyists to force through deregulation laws in financial markets (Acemoglu, 2011).

As may be noted, the Gini coefficient displays different trends for the EU28 and the euro area. For the former there seems to be a decreasing trend, at least until 2009, after which it stabilises at around 0.35. The Gini coefficient in the euro area, though smaller than that in the EU-28, has slowly increased, especially after the crisis, to a peak of 0.32 in 2013 (Filauro, 2018).

It is also characteristic that in most OECD member countries, the decline in wage growth affects the entire distribution of wages - it fell for the lowest decile, the median, and the highest decile of wages. However, the pace of wage growth continues to be diversified - the wages of the top 1 percent of earners grow clearly faster than the median wage.

After the financial crisis, the decline in unemployment in OECD member countries has had a clearly weaker impact on wage growth than previously. In recent years, the annual increase in wages was by approximately 1.5 to 2 percentage points lower than during similar levels of unemployment in 20002007 (Wroński, 2018). 
Extreme inequalities always lead to conflicts, which, in turn, hold back investments. Increasing disparities cause current economic policies to focus on protectionism, globalisation-hindering attitudes and pro-market reforms, rather than on policies supporting economic growth (Claessens \& Perotti, 2007).

In general, the negative effects of the financial crisis have sparked more insightful research into sources of inequalities, their effects, and recommendations for economic policies (Filauro, 2018; Gradín, 2016; Maqueda, 2018; Villar Rubio, Rubio, Manuel, \& Molina Moreno, 2015; Wroński, 2018).

These factors may affect the level of disparity between countries as well as the level of inequalities within countries. Research has shown that the trends of the between-region inequality component for the EU and the euro area mirror those obtained for the between-country component, albeit at higher levels, as the inequality between regions is greater than that between countries for both the EU-28 and the euro area.

This is supported by statistical data. The Eurostat Regional Yearbook (2018) rate the question as a serious one and identify three characteristics of territorial inequality in Europe that needs to be highlighted. The first is that there is a very high level of regional economic inequality. GDP per capita in the richest NUTS 2 region in the EU (Inner London) is over five times (5.8 in 2015) higher than the average for the EU-28. At the other extreme, the poorest regions have levels of GDP per capita that are less than half the EU average (Diez-Minguela, MartinezGalarraga, \& Tirado-Fabregat, 2018) (Diez-Minguela et al., 2018).

These observations warrant an investigation into which inequality-forming processes are present in selected member states of the European Union, which hails cohesion policy and equalising the opportunities of poorer regions as its priorities.

This article is a continuation of the authors' research into various models of income distribution in the countries under investigation. The initial study concerned the years 1999 to 2007 (Błażejowski et al., 2012). The models presented here relate to the period from 2000 to 2015 and reveal evidence of the effects of the 2008 financial meltdown. The analysis covers a group of six European economies, including Germany, France, Italy, the UK, Spain, and Poland.

From a statistical point of view, selection of this group of countries is justified by the fact that in total it represents $60 \%$ of the regions of the European Union, $70 \%$ of its population and $70 \%$ of its GDP. In addition, the experience and political significance of the first four countries allows them to be used as a reference point for converging economies, which is illustrated in Figure 1.

The positively inclined demarcation line in Figure 1 is the result of connecting dots representing the relationship between GDP per capita and number of persons employed throughout the European Union. It clearly separates the abovementioned countries from the others, which, while having different levels of GDP per capita, represent lower population potential and thus employment potential. Hence, the countries examined in this study are considered to be large European economies. 
Figure 1. ReLAtionship between nUmber of PeRsons employed AGed 15-64 (In thousAnd) ANd GDP PER CAPITA (IN EUR) IN 2016

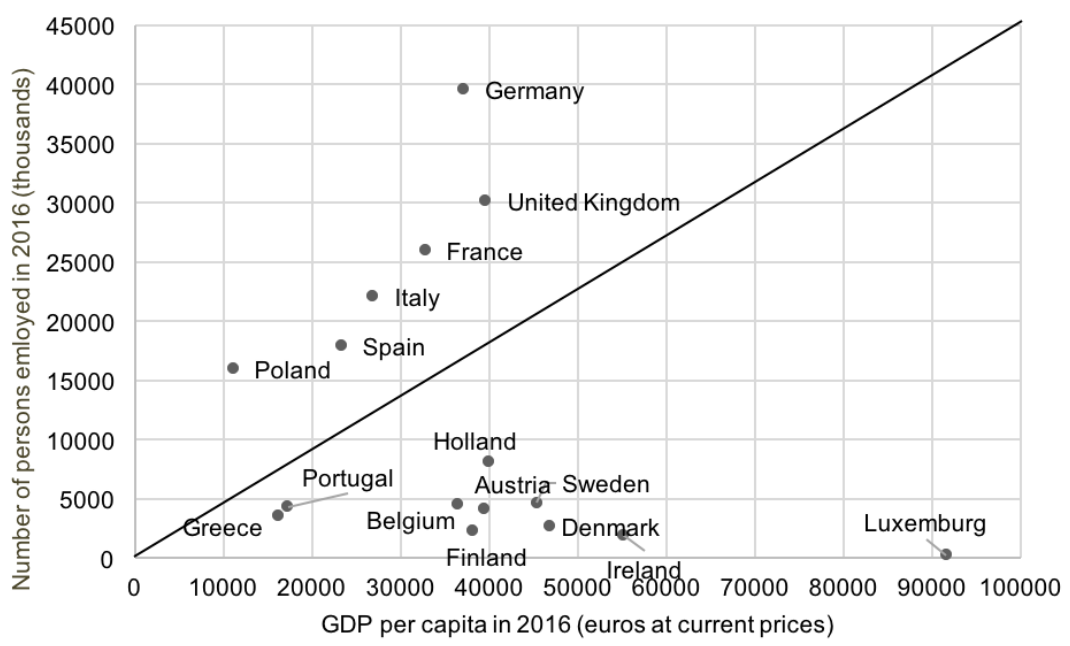

Source: own calculations based on Eurostat database (https:/ec.europa.eu/eurostat/data/database).

The main objective of the research was to test the distribution of income at regional level (NUTS2) in those economies and to attempt to identify the differences between them. In addition, a decision was made to analyse the impact of two events on the level of regional inequalities in those countries: enlargement of the EU and the 2008 financial crisis. In both cases, the economic environment and the economic situation changed in all the countries under consideration. In the first case, funding was reallocated to the new Member States and new sales markets opened, while in the second, all countries experienced, albeit to varying degrees, the economic effects of the crisis.

During the period under consideration, all those countries experienced economic growth, as measured by GDP per capita. However, this positive phenomenon was accompanied by various changes in terms of regional income diversification.

In the absence of a clear criterion for the occurrence of these differences, the analysis is based on a theoretical assumption that the most desired state is economic growth while maintaining regional distribution of income as close to normal as possible. In a situation where only a small number of regions are responsible for the high rate of GDP growth at country level, there is a growing stratification of income. The longer this tendency is present, the more negative its social consequences become.

The literature on income inequalities is full of statistical studies, which are focused both on inequalities within an economy as well as on differences between economies. The have been various methods used, depending on the scope of 
research and the availability of datasets at the NUTS2 level. The most standard measures used is such research are such as coefficient of variation, Gini coefficient, income distribution by quintiles, poverty index or gender gap index. In this article, the coefficient of variation is used as the standard measure of income inequalities, while in order to produce the empirical distribution of income, the nonparametric method of the kernel density estimation has been used. The main advantage of such a method is the independence of a priori assumed theoretical distribution.

\section{MACROECONOMIC SITUATION AROUND TIPPING POINTS}

The fundamental criterion in assessing the level of development of individual economies is GDP per capita, which finally reflects the cumulative rate of economic growth for the periods under investigation. The data in Table 1 show both the scale of economic growth over time in each country and the changes in relations between them. Looking at the extreme years, it can be noted that between 2000 and 2015 GDP per capita grew in Germany by 16,850 euros, in the UK by 14,607 euros, in France by 12,734 euros, in Italy by 10,210 euros, in Spain by 12,459 euros, and in Poland by 13,518 euros. These changes result from the rate of economic growth throughout the analysed period, economic fluctuations, and the so-called base effect. Indirectly, they point to the process of richer countries being caught up with by countries such as Spain and Poland, but also the process of the most economically advanced economies, such as Germany or the UK, increasing their lead. Thus, in terms of GDP per capita, the relations between those countries have changed, in particular in comparison to the long-standing top performer, Germany. For example, in 2000 the difference in GDP per capita between Germany and Spain amounted to 5,539 euros, but in 2015 it increased to 9,930 euros. In the case of Poland, those differences amounted to 12,453 euros and 15,785 euros in 2000 and 2015 , respectively.

Table 1. GDP per capita in Large EuRopean Economies in SElected years (DATA IN EUR according TO PPS $(2015=100))$.

\begin{tabular}{|l|r|r|r|r|}
\hline Country & \multicolumn{1}{|c|}{2000} & 2004 & 2008 & \multicolumn{1}{c|}{2015} \\
\hline Germany & 18985 & 22421 & 27655 & 35835 \\
\hline United Kingdom & 16576 & 20447 & 24136 & 31183 \\
\hline France & 18009 & 20984 & 25746 & 30743 \\
\hline Italy & 17604 & 20449 & 25322 & 27814 \\
\hline Spain & 13446 & 17874 & 24464 & 25905 \\
\hline Poland & 6532 & 8854 & 12563 & 20050 \\
\hline
\end{tabular}

Source: own calculations based on Eurostat database (https://ec.europa.eu/eurostat/data/database). 
The ratio of Poland's to Spain's GDP per capita in 2000 showed Spain's advantage by 6,914 euros in GDP per capita, but in 2015 it fell to 5,855 euros. The dwindling differences in GDP per capita between countries indicate an ongoing convergence process. However, this process is not necessarily synonymous with an expected decrease in territorial differences.

From the point of view of the two boundary time points, it is worth looking at key macroeconomic parameters such as real GDP growth rate, average annual HICP, general government deficit/CDP, average annual unemployment rate, and net export/GDP. This set of indicators is referred to as the macroeconomic stabilisation pentagon (Kołodko, 1993).

Table 2. Selected indicators 2003 - 2005 as a result of EU enlargement in 2004

\begin{tabular}{|c|c|c|c|c|c|c|c|c|c|c|c|c|c|c|c|}
\hline \multirow{2}{*}{ Country } & \multicolumn{3}{|c|}{ Real GDP growth rate } & \multicolumn{3}{|c|}{ Average annual HICP } & \multicolumn{3}{|c|}{$\begin{array}{l}\text { General government } \\
\text { deficit/GDP }\end{array}$} & \multicolumn{3}{|c|}{$\begin{array}{l}\text { Average annual unem- } \\
\text { ployment rate }\end{array}$} & \multicolumn{3}{|c|}{ Net export/GDP } \\
\hline & 2003 & 2004 & 2005 & 2003 & 2004 & 2005 & 2003 & 2004 & 2005 & 2003 & 2004 & 2005 & 2003 & 2004 & 2005 \\
\hline DE & $-0,7$ & 1,2 & 0,7 & 1,1 & 1,8 & 1,9 & $-4,2$ & $-3,7$ & $-3,4$ & 9,7 & 10,4 & 11,2 & 3,7 & 5.0 & 5,1 \\
\hline ES & 3,2 & 3,2 & 3,7 & 3,1 & 3,1 & 3,4 & $-0,4$ & 0,0 & 1,2 & 11,5 & 11 & 9,2 & $-2,2$ & $-3,9$ & $-5,0$ \\
\hline FR & 0,8 & 2,8 & 1,7 & 2,2 & 2,3 & 1,9 & -4 & $-3,6$ & $-3,4$ & 8,5 & 8,9 & 8,9 & 1,4 & 1,0 & 0,1 \\
\hline IT & 0,2 & 1,6 & 0,9 & 2,8 & 2,3 & 2,2 & $-3,3$ & $-3,5$ & $-4,1$ & 8,4 & 8 & 7,7 & 0,5 & 0,6 & $-0,1$ \\
\hline $\mathrm{PL}$ & 3,6 & 5,1 & 3,5 & 0,7 & 3,6 & 2,2 & $-6,1$ & -5 & -4 & 19,8 & 19,1 & 17,9 & $-2,7$ & $-2,7$ & $-1,1$ \\
\hline UKgg & 3,3 & 2,3 & 3,1 & 1,4 & 1,3 & 2,1 & $-3,1$ & $-3,1$ & $-3,1$ & 5,0 & 4,7 & 4,8 & $-2,4$ & $-2,6$ & $-2,5$ \\
\hline
\end{tabular}

Source: own calculations based on Eurostat database (https://ec.europa.eu/eurostat/data/database).

The above indicators indirectly include the broadly understood component of EU enlargement and its socio-economic effects.

Firstly, the data show that a convergence process was under way because the GDP growth rate in Spain and Poland was on average higher than in the other advanced economies (except for the UK), which was related to the on average higher unemployment rate. In the studied group of countries, this was particularly true about Poland, which resulted in a high wave of emigration, mainly to the UK.

Secondly, during the years 2000-2006 cohesion policy funds were initially funneled only into four countries (Greece, Spain, Ireland, and Portugal), and from 2004 into all new Member States. The accession of a fairly large number of poorer regions to the European Union in 2004 meant that the poorer regions of the "old" EU-15 were no longer eligible for support under the Objective 1 supporting "Convergence". However, many of these regions could receive support from other funds under the Objective 2 "Regional Competitiveness and Employment". The largest beneficiaries of cohesion policy alone, on top of 
other transfers of funding, was Spain prior to the enlargement (12,357 million euros) and Poland after the enlargement (4,178.6 million euros).

In connection with the EU enlargement, greater activation of export flows could be observed in the most developed economies, which were mainly destined for the new Member States due to the growing consumption and investment demand (Antoniewicz et al., 2017).

Thirdly, in the period around the accession, both the average annual HICP and the general government deficit / GDP in each country did not diverge drastically from the Maastricht criteria. In 2005, only Italy and Poland had a relatively higher general government deficit / GDP.

The second key event was the 2008 financial crisis. Its first effects widely revealed themselves in 2009, although some countries were already experiencing them in 2008. The differences between the countries under consideration can be illustrated by changes in selected indicators, the same as in Table 2, in the years 2007-2009.

Table 3. Selected indicators 2007 - 2009 as a Result of the finanCial CRISIS

\begin{tabular}{|c|c|c|c|c|c|c|c|c|c|c|c|c|c|c|c|}
\hline \multirow{2}{*}{ Country } & \multicolumn{3}{|c|}{$\begin{array}{l}\text { Real GDP } \\
\text { Growth Rate }\end{array}$} & \multicolumn{3}{|c|}{$\begin{array}{c}\text { Average Annual } \\
\text { HICP }\end{array}$} & \multicolumn{3}{|c|}{$\begin{array}{c}\text { General Government } \\
\text { Deficit / GDP }\end{array}$} & \multicolumn{3}{|c|}{$\begin{array}{c}\text { Average annual } \\
\text { unemployment rate }\end{array}$} & \multicolumn{3}{|c|}{ Net Export/GDP } \\
\hline & 2007 & 2008 & 2009 & 2007 & 2008 & 2009 & 2007 & 2008 & 2009 & 2007 & 2008 & 2009 & 2007 & 2008 & 2009 \\
\hline DE & 3,3 & 1,1 & $-5,6$ & 2,3 & 2,8 & 0,2 & 0,2 & $-0,2$ & $-3,2$ & 8,5 & 7,4 & 7,6 & 6,6 & 6,0 & 4,9 \\
\hline ES & 3,8 & 1,1 & $-3,6$ & 2,8 & 4,1 & $-0,2$ & 1,9 & $-4,4$ & -11 & 8,2 & 11,3 & 17,9 & $-6,0$ & $-5,1$ & $-1,2$ \\
\hline FR & 2,4 & 0,3 & $-2,9$ & 1,6 & 3,2 & 0,1 & $-2,6$ & $-3,3$ & $-7,2$ & 8,0 & 7,4 & 9,1 & $-0,7$ & $-1,2$ & $-0,8$ \\
\hline IT & 1,5 & $-1,1$ & $-5,5$ & 2,0 & 3,5 & 0,8 & $-1,5$ & $-2,6$ & $-5,2$ & 6,1 & 6,7 & 7,7 & $-0,4$ & $-0,8$ & $-0,7$ \\
\hline $\mathrm{PL}$ & 7,0 & 4,2 & 2,8 & 2,6 & 4,2 & 4 & $-1,9$ & $-3,6$ & $-7,3$ & 9,6 & 7,1 & 8,1 & $-3,5$ & -5 & $-0,9$ \\
\hline UK & 2,5 & $-0,3$ & $-4,2$ & 2,3 & 3,6 & 2,2 & $-2,6$ & $-5,2$ & $-10,1$ & 5,3 & 5,6 & 7,6 & $-2,3$ & $-2,5$ & $-1,8$ \\
\hline
\end{tabular}

Source: own calculations based on Eurostat database (https://ec.europa.eu/eurostat/data/database).

The data indicate that across all countries the cost of the crisis was reflected as a decline in the GDP growth rate and, in the majority of the countries (except for Germany), a decrease in the net export to GDP ratio. In Germany, the scale of the decline in GDP growth in 2009 compared to 2007 was the strongest among the countries under consideration, similar to that in Italy. What stands out, however, is that in Germany this happened while the unemployment rate dropped, which is a demonstration of a policy of labour market protection. On the other hand, in Spain in particular, but also in the UK, France and Italy, the unemployment rate in 2009 turned out to be higher than 
in 2007. Furthermore, in Spain, the sharp increase in the unemployment rate was combined with deeply negative net export to GDP ratios.

In Poland, as a country which in that period was relatively less included in the global economy, this indicator in 2008 was at a similar level as in Spain.

Thirdly, in comparison to the period around accession, all countries rapidly increased their budget deficit in 2009; in the case of Spain and the UK - about three times in relation to the Maastricht criteria. This was accompanied by low inflation, ranging from 0 to 1 .

The above general economic assessment, which focused on two periods: 2003 to 2005 and 2007 to 2009, concerns the whole economy and provides an introduction to the assessment of income distribution at regional level and answering the question of what consequences of two non-standard events in the period 2000-2015 can be observed in terms of income inequality at regional level.

\section{RESEARCH METHODS}

The income distribution study takes 2000, 2004, 2008 and 2015 as the representative years. The rationale behind comparing those years is that 2000 and 2015 mark the start and the end of the analysis; 2004 is important due to the enlargement of the EU; while 2008 is the last year in which GDP per capita grew in all analysed economies, after which, in 2009, GDP data clearly reflected the 2008 financial crisis.

In order to determine the dispersion level of GDP per capita among the regions of the country, the standard deviation is usually used, however, it is a measure that detects the absolute differences in the distribution of the given feature. The phenomenon of the increasing level of standard deviation determined on the basis of the GDP per capita levels of the NUTS2 regions for the economies studied may suggest the occurrence of a $\sigma$ divergence process, but it is worth noting that the increasing level of the standard deviation can be solely the result of the rise in the average level of GDP per capita. In order to eliminate the potential error in the interpretation of the $\sigma$ convergence, the coefficient of variation is used, which has the advantage of detecting the relative variation of the features (in this case, GDP per capita). The coefficient of variation that decreases with time means that $\sigma$ convergence process is observed.

Simple $\sigma$ convergence measures, such as standard deviation and coefficient of variation provide relevant information, however such an approach may also be considered as insufficient (Quah, 1993; Wójcik, 2004). It seems much more interesting the analysis of the dynamics of distribution of the variable and internal mobility within it over time (Wójcik, 2016). It is possible to perform such an analysis by applying kernel density estimation. Consequently, an attempt was made to estimate the distribution of domestic income based on observations of the average GDP per capita in the NUTS2 regions. The importance of the given NUTS2 region in the country was based on the population of the 
region. Such an approach, at least in part, denies the excessively restrictive hypothesis of being able to identify the income of the citizen with the average income of the region. In order to reproduce the distribution of income, the nonparametric method has been used, which has the advantage of abstracting from the assumption of the arbitrary form of distribution function. The idea of using the kernel density estimator consists of reproducing the distribution in the population through the punctual information of the probability distribution in the closest surroundings of the point. The kernel density estimator for the function $\mathrm{K}$ takes the following form

$$
\widehat{f_{k}}=\frac{1}{q h} \sum_{i=1}^{n} W_{i} K\left(\frac{x-X_{i}}{h}\right)
$$

where:

- $n$ - the number of points at which the density estimate is to be evaluated;

- $q=\sum_{i} w_{i}=n$, which means that analytic weights were used,

- $\quad x-X_{i}$ - the width of the density window around each point,

- $h$ - smoothing parameter of the function $f_{k}$.

The study used the Epanechnikov function (1969), which is characterized by the minimum mean integrated squared error and takes the following form:

$$
K[z]=\left\{\begin{array}{c}
\frac{3}{4}\left(1-z^{2}\right),|z|<1 \\
0,|z| \geq 1
\end{array}\right.
$$

There is the opinion that the choice of the $\mathrm{K}$ function is not as critical as the selection of adequate bandwidth (h) (see Heidenreich, Schindler, \& Sperlich, 2010; Zambom \& Dias, 2013). The choice of bandwidth determines the degree of smoothing of the density graph. Marking the scale that is too wide affects the excessive smoothing, so that the local ends cannot be observed. In turn, the use of the window too narrow would make interpretation difficult, since the density function would have many narrow peaks and valleys between them (Wójcik, 2016). In the analysis, the $h$ parameter was determined arbitrarily according to the prevailing opinion in the literature (see Sala-i-Martin, 2006) 1 :

$$
h=\frac{0,9 \sqrt{\sigma^{2}}}{\sqrt[5]{n}}
$$

1 Smoothing parameter $\boldsymbol{h}$ was calculated for each year individually for all the counties under investigation. 
where:

- $\sqrt{\sigma^{2}}$ - standard deviation weighted by the population of each region.

From the point of view of interpretation, it is important to link the aforementioned measures and consider the relative correspondence between them. In this paper, coefficient of variation is used as the most representative simple measure, and as its complement, which is the estimated income distribution.

4. BASIC MEASURES OF INCOME DISPARITY AND THE DISTRIBUTION OF REGIONAL INCOME LEVELS IN LARGE EUROPEAN ECONOMIES

In classical studies on sigma convergence the most often used measure has been the coefficient of variation. This measure is presented for the entire research period in Figure 3. In order to maintain comparability between countries, it was decided to keep the same scale on the vertical axis for all countries. In addition, a linear equation (trend line) was estimated for each country. The estimated trend line clearly indicates the tendency for the coefficient of variation.

Figure 3 shows that the coefficient of variation had the highest values in UK regions, which means that the level of stratification in this country was the highest in the analysed period. In the case of the other economies, this coefficient was more than half lower. Apart from French regions, it was below $30 \%$. Interestingly, in UK regions, the value of the coefficient of variation was rising, which indicates that stratification in the period under consideration was systematically growing. The estimated directional coefficient for the trend function took the value 0.0123 , which means that annually the average level of stratification increased by $1.23 \% 2$. The coefficient of variation estimated for French and Polish regions displayed similar tendencies. The growth rate of income stratification in French regions amounted to 0.0047 during the period under consideration, which means that regional stratification in France grew at a rate of $0.47 \%$ per annum3.

In the case of Polish regions, as in the case of the UK and France, the estimated directional coefficient for the trend function also had a positive value (0.0033) and was statistically significant4. Observation of changes in the coefficient of variation for Poland shows that income stratification between its NUTS2 regions increased, on average, by $0.33 \%$ annually. The relative level of this stratification is not as high as in the UK, and the trend itself is not as strong as in the case of either the UK or France. Those changes should be, however, considered undesirable.

\footnotetext{
2 The slope coefficient in the trendline is significant at the $1 \%$ level.

3 In case of Germany and France the value of the slope coefficient in the trendline is significant at the $1 \%$ level.

${ }^{4}$ The slope coefficient in the trendline is significant at the $1 \%$ level.
} 
Figure 3. InCOME DIFFERENCES IN THE LARGE EUROPEAN ECONOMIES MEASURED BY THE COEFFICIENT OF VARIATION IN THE PERIOD 2004-2015

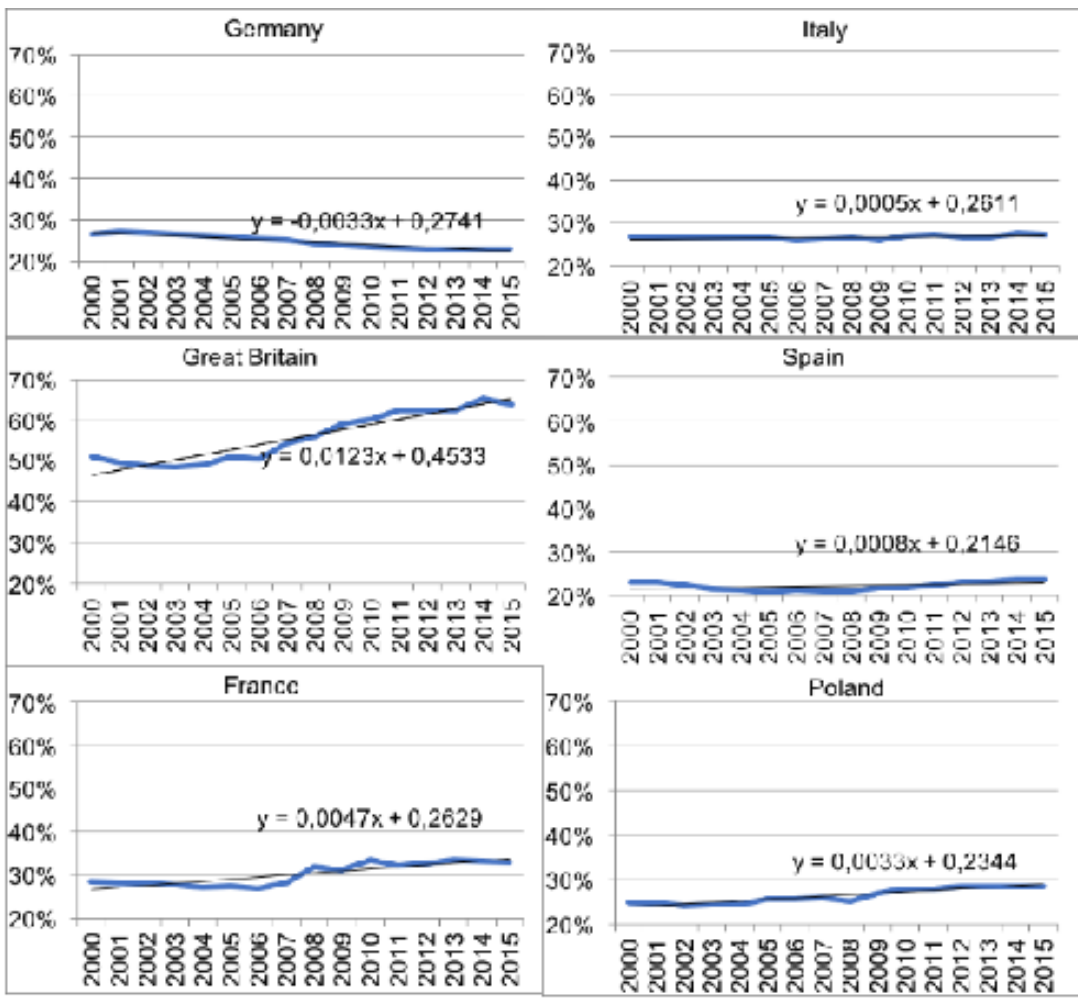

Source: own calculations based on Eurostat database (https:/ec.europa.eu/eurostat/data/database)

When comparing trends in the other economies, it should be noted that only in the case of German regions there was a statistically significant fall in stratification at the rate of $0.33 \%$ per year, which warrants the conclusion that a sigma convergence process was in progress. Coupled with the relatively low level of stratification in the initial period, the situation in this country should be considered positive in comparison with other large European economies. On the other hand, in the case of Italy and Spain, the estimated directional coefficient for the trend function was not statistically significantly different from zero, which means that there were no premises for inferring that a sigma convergence process was present, and income stratification at the level of NUTS2 regions should be considered stable in the observed period5.

${ }^{5}$ For both Italy and Spain, the directional coefficient of the trend function is negligibly different from zero at $5 \%$ significance level. 
The presented coefficients of variation encourage more in-depth research and analysis of distribution of regional income levels.

Using the kernel probability density estimator based on GDP per capita data for NUTS2 regions of a given country and weights resulting from the population density of a given region, empirical income distributions for the analysed economies were obtained. It was decided to show graphs for four arbitrarily selected points over time, because showing the estimated probability density functions for a larger number of years immeasurably reduces the readability of the graphs and the possibility of their interpretation. Figures 4 and 5 show the distribution of regional incomes in large European economies. Figure 4 presents income distributions for the most developed economies: Germany, the UK, and France, while Figure 5 presents income distributions for Italy, Spain, and Poland. Each graph uses a uniform range of values on the ordinate axis and on the abscissa axis, so as to preserve far-reaching comparability of the results obtained. An assessment of the distribution of incomes should answer the following questions:

- Is the resulting distribution is close to unimodal distribution, or is there is more than one extreme and, therefore, the distribution is bimodal or multimodal?

- $\quad$ Does the shape, and more specifically the kurtosis of the graph, show a concentration of observations around the mode (or modes, in the case of multimodal distribution)?

- Was there a shift to the right and what was the scale of this shift over time?

Based on observation of the direction and scale of the shift, one can infer whether the right side of the graph, associated with the richer regions, and the left side, associated with the poorer regions, moved at a similar pace, regardless of whether the distribution is unimodal, bimodal or multimodal.

The income distribution for Germany estimated on the basis of data for NUTS2 regions is close to the normal distribution, however, in 2000, 2004 and 2008 two local maxima were also observable (to the right and to the left of the entire distribution's maximum). This means that the income of most regions was concentrated around the mode (global extreme), but a group of slightly poorer and a group of somewhat richer regions also appeared. The estimated distribution for 2015 shows that the left mode was disappearing, while the regions with a relatively higher level of GDP per capita were still noticeable. However, this does not warrant a finding of a typical bimodal distribution, because the vast majority is clustered around the global extreme value, and the richer regions form a local extreme with much lower probability density. In dynamic terms, the regional income distribution graph has become flat, which suggests that absolute differences between the regions have increased, while relative dispersion measures do not confirm this. This is a result of economic growth, which is represented by a shift of the graph to the right. When it comes to shifting of the global extreme and local extremes to the right, it is impossible to unambiguously determine which of the extremes has shifted more, which 
Figure 4: Regional income density functions in Germany, United Kingdom, France in Selected YEARS (X-AXIS - INCOME MEASURED IN THOUSANDS OF EUR IN PPS AT 2015 PRICES; Y-AXIS - DENSITY)

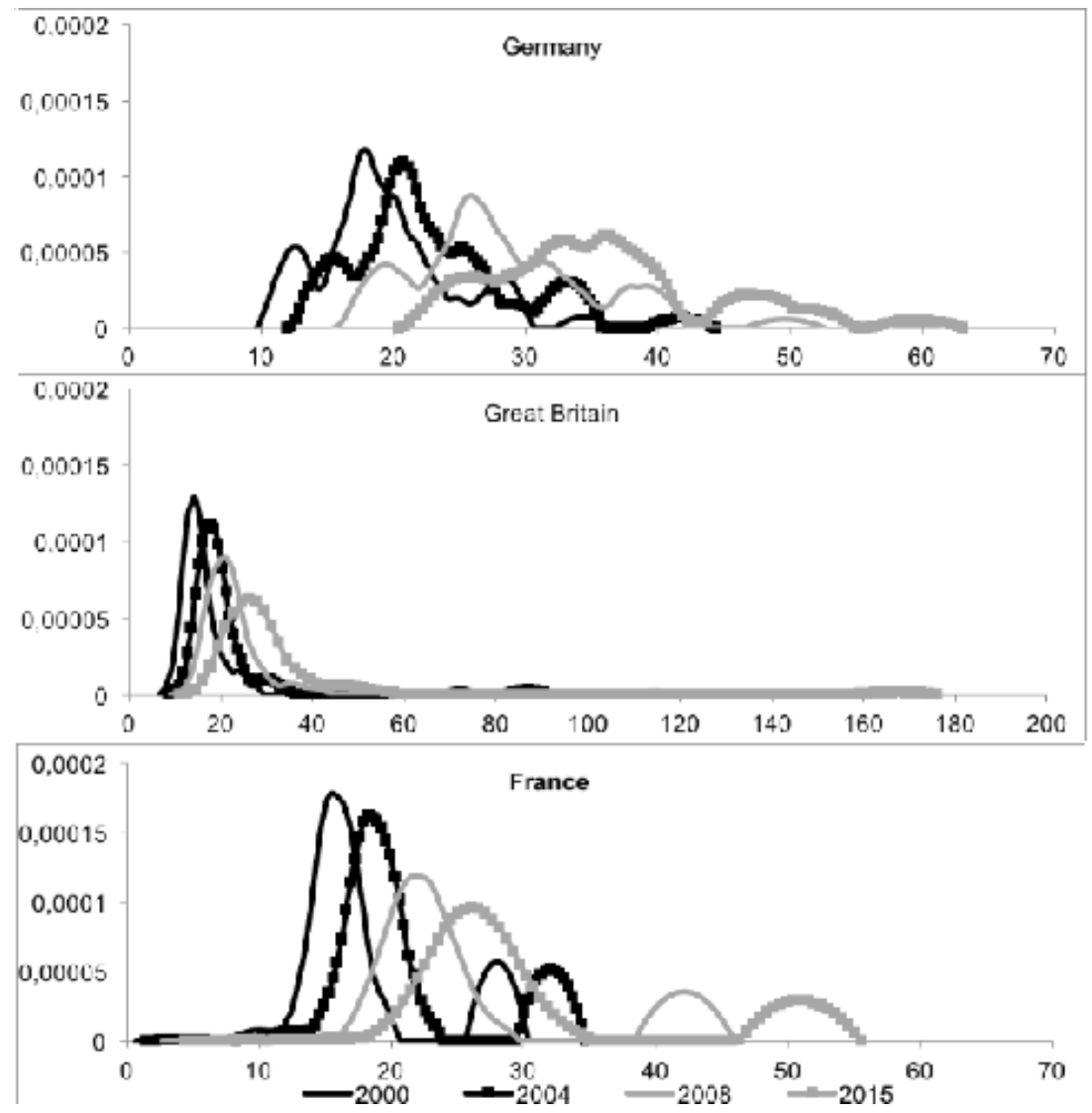

Source: own calculations based on Eurostat database (https://ec.europa.eu/eurostat/data/database).

means that German regions can still be considered to have relatively "normal" distribution.

The UK income distribution estimated on the basis of data on NUTS2 regions is quite different than that of Germany, and the general characteristics of this distribution did not change during the period under consideration. All regions except the capital (two London regions) form one mode, while the capital regions form a local extreme shifted strongly to the right. The distribution for the dominant part of the poorer regions (excluding the capital regions) resembles the normal distribution, but this is only due to the quite high smoothing parameter, which is in 
line with a priori assumptions ${ }^{6}$. As in the case of the distribution for Germany, the graph tends to become flatter, suggesting that the absolute differences between the regions have increased. This is also confirmed by the relative measures of dispersion. However, the most important feature of income distribution for UK regions in dynamic terms is that the income of the capital regions experienced a several times higher rate of growth than the other regions. This is illustrated on the graph by the strong shift of the local extreme to the right, while the distribution for the other regions has shifted to a relatively small extent. Due to such large stratification between the London regions and other UK regions, a question arises whether income distributions in this economy should be interpreted as a whole.

France paints a picture similar to that of the UK. In both cases, one can speak of a bimodal distribution, where the vast majority of regions form a global extreme with a lower income level, and a local extreme with a higher income level is created basically by a single (capital) region. The main difference, however, is that the distance between those modes is not as large as in the case of the UK. In France, the capital region's income is about twice as high as the level of income for other regions, while in the UK this value is several times higher (more than five times in 2015). Similarly, to Germany and the UK, there is a tendency for the French income distribution graph to flatten, which means that the absolute differences in income are increasing.

Figure 5 shows the estimated income distributions for the other three large European economies. The distribution of income in Italy indicates a typical bimodal distribution, with both modes being formed by similar numbers of regions. It is worth noting that there are no regions with average income levels. Analysis of that income distribution reveals a classical division into two groups: poorer and richer regions, with the richer regions being in slight majority. However, this situation is similar to that observed in the UK and France only to a small degree, because in the case of Italy, the second mode is formed by an entire group of regions, not just the capital region(s). As in the case of previously analysed economies, certain flattening of the graph can be observed, which translates into increasing stratification in absolute terms (the modes become more platykurtic). The whole graph shifted in the period under consideration to the right, which means that economic growth was taking place, however, the shift was not even. The right mode moved to the right faster, which means that the group of regions which were richer in absolute terms was becoming increasingly richer. The differences in the shifting of the modes are particularly visible in the period after 2008. In the case of poorer regions, the shift was slight, while both the left and the right arm of the mode created by the richer regions shifted to a much greater degree. On the basis of the observed changes in income distribution, it can be concluded that a process of growing stratification, or differentiation, is occurring.

\footnotetext{
${ }^{6}$ The high value of the smoothing parameter $(\boldsymbol{h})$ it is caused by a high value of standard deviation, which is disturbed by high GDP per capita values for the capital regions compared to GDP per capita of the rest of the regions at NUTS2 level.
} 
Figure 5: Regional income density functions in Italy, Spain, Poland in selected years (X-axis INCOME MEASURED IN THOUSANDS OF EUR IN PPS AT 2015 PRICES; Y-AXIS - DENSITY)

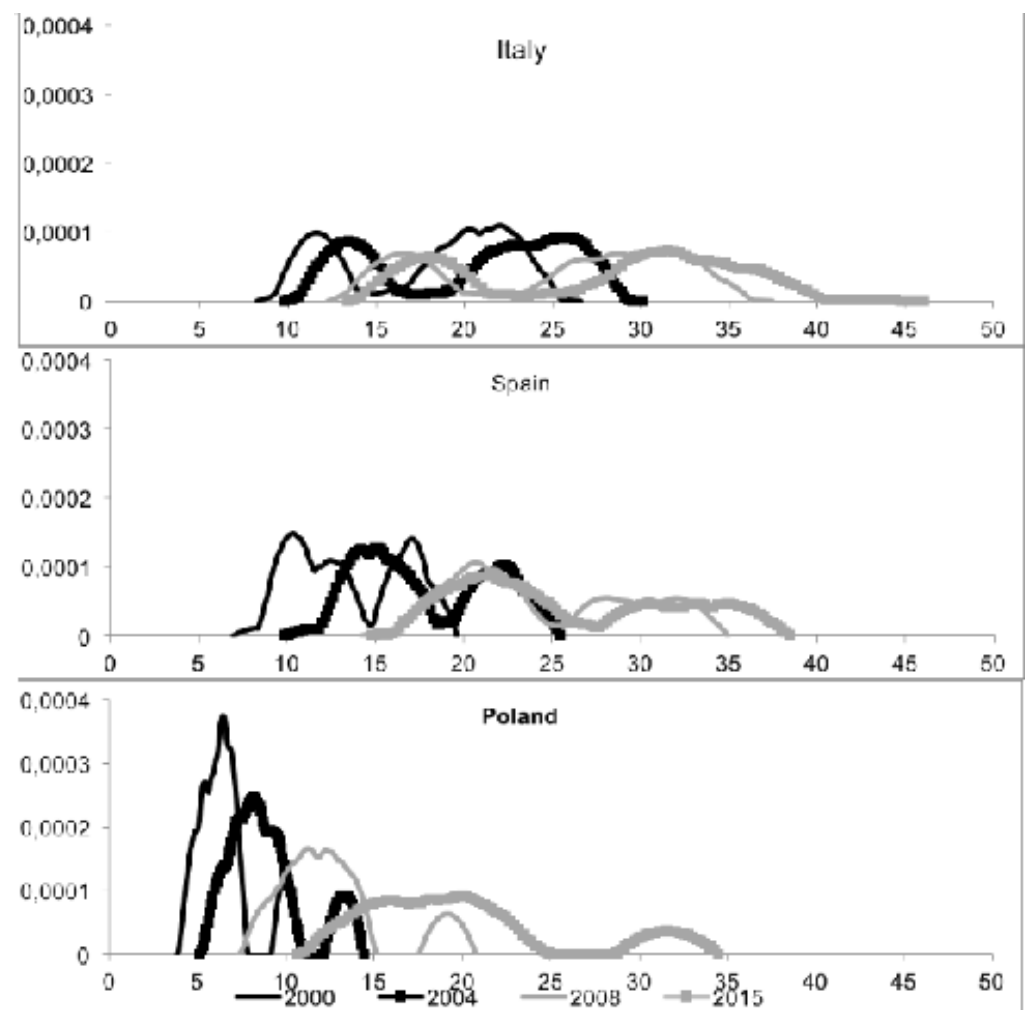

Source: own calculations based on Eurostat database (https://ec.europa.eu/eurostat/data/database).

A distribution of regional incomes similar to that for Italy was estimated for Spain, namely a bimodal distribution with similarly sized modes. The main difference is that the right mode was less numerous at the beginning of the period under consideration and it became even less numerous and more dispersed during that period. The second important observation is that the difference between the modes is not as significant as in the case of Italian economy. The distribution of incomes in the regions of Spain is more similar to their distribution in Germany than that in Italy, with the difference that the second mode in Germany was even less numerous. If perhaps a slightly higher smoothing parameter was applied, it could turn out that an unimodal distribution would be obtained. As in the case of the previously analysed economies, the income distribution graph became flatter, which is a symptom of increasing stratification in accordance with absolute measures. As for dynamic analysis, it is worth noting that until the 
global crisis, both modes had been shifting to the right in a similar way, while in the post-crisis period the left mode barely changed its position, while the right mode shifted to the right. It means that after 2008 richer regions experienced higher growth rates. This, in turn, translates into increasing stratification in both absolute and relative terms.

In Poland, from the beginning of the analysed period, a bimodal distribution could be observed, with a dominant group of regions forming the left mode and a small group creating the right mode. When examining primary data, it should be noted that it was, in fact, the capital region that was responsible for the creation of the right mode (richer regions), which shows similarity to the UK and the French distribution. As in the other cases, the distribution graph tended to flatten over subsequent measurement points, which is particularly evident in the case of the left mode. The cluster of regions which formed it was increasingly stratified in absolute terms. The whole graph was shifting strongly to the right in the analysed period, which indicates high economic growth, but the difference in the level of income between the extremes of both modes was definitely growing. This means that the capital region was developing at an above average pace in relation to other regions. In Poland, therefore, increasing stratification was observed in both relative and absolute terms.

So far, the analysis of income inequalities at the level of regions signals a general tendency for them to grow. The question arises whether these observations are connected with any triggers that took place around the accession years and during the financial crisis.

TABLE 4. GDP per CAPITA AND COEFFICIENT OF VARIATION In SELECTED YEARS [DATA IN EUR ACCORDING to PPS $(2015=100)]$

\begin{tabular}{|c|c|c|c|c|c|}
\hline Country & Measure & 2000 & 2004 & 2008 & 2015 \\
\hline \multirow{2}{*}{ DE } & average & 19395,46 & 22900,17 & 28246,14 & 35842,87 \\
\hline & $\begin{array}{l}\text { coefficient of } \\
\text { variation }\end{array}$ & $26,32 \%$ & $26,05 \%$ & $24,14 \%$ & $22,92 \%$ \\
\hline \multirow[b]{2}{*}{$\mathrm{FR}$} & average & 17944,51 & 20923,46 & 25671,16 & 30585,98 \\
\hline & $\begin{array}{l}\text { coefficient of } \\
\text { variation }\end{array}$ & $28,60 \%$ & $27,11 \%$ & $31,96 \%$ & $33,00 \%$ \\
\hline \multirow[b]{2}{*}{ IT } & average & 17784,59 & 20541,36 & 25238,84 & 27762,47 \\
\hline & $\begin{array}{l}\text { coefficient of } \\
\text { variation }\end{array}$ & $26,51 \%$ & $26,54 \%$ & $26,43 \%$ & $27,06 \%$ \\
\hline \multirow[b]{2}{*}{ ES } & average & 13521,21 & 17910,66 & 24417,94 & 25907,86 \\
\hline & $\begin{array}{l}\text { coefficient of } \\
\text { variation }\end{array}$ & $23,15 \%$ & $21,15 \%$ & $21,00 \%$ & $23,61 \%$ \\
\hline \multirow{2}{*}{ PL } & average & 6564,24 & 8872,53 & 12592,77 & 19794,46 \\
\hline & $\begin{array}{l}\text { coefficient of } \\
\text { variation }\end{array}$ & $24,71 \%$ & $24,36 \%$ & $24,94 \%$ & $28,37 \%$ \\
\hline \multirow{2}{*}{ UK } & average & 16361,03 & 20219,57 & 23701,39 & 30877,41 \\
\hline & $\begin{array}{l}\text { coefficient of } \\
\text { variation }\end{array}$ & $50,85 \%$ & $48,94 \%$ & $55,86 \%$ & $63,81 \%$ \\
\hline
\end{tabular}

Source: own calculations based on Eurostat database (https://ec.europa.eu/eurostat/data/database). 
For this purpose, Tables 4 and 5 summarise data for the four points in time considered, regarding average GDP per capita, coefficient of variation and selected indicators describing the relationship between the poorest and the richest regions.

As is evident from the data in Table 4, GDP per capita grew on average over the period under consideration in all economies with high coefficient of variation. In 2015, it was definitely the highest in the UK, followed by France. When it comes to changes over time in the desired direction (systematic decline), this phenomenon could be observed only in Germany. In France, Italy, and the UK, a step increase in inequalities took place in 2008, while in Poland and Spain - in 2015.

As demonstrated by income distributions, the rise in disparities resulted mainly from the emergence of a second mode in many countries, usually associated with the capital region.

In this context, indicators of the share of the poorest region in relation to the richest region in a given country, and their change over time, as presented in Table 5, provide a complementary insight. Both the value of the minimum/ maximum ratio and the direction of changes are significant. In 2000, which was the kick-off point for the analysis, those proportions were relatively the most favourable in Spain, followed by Poland, Italy, and Germany, and definitely unfavourable in the UK and France due to the rich capital regions (London and Paris). A comparison of change dynamics shows that the minimum/maximum ratio systematically increased in Germany and France, albeit with a significant differentiation of its level in favour of Germany. In the other countries, the initial upward trends halted either in 2008 (UK) or in 2015 (IT, ES, PL). This means that the GDP per capita of the capital region grew much faster in this period than in other regions. In order to eliminate the potential impact of the richest region on the values of the minimum/maximum ratio, the $\mathrm{Q} 1 / \mathrm{O} 3 \mathrm{ratio}$, or the relation of the first to the third quartile, was additionally estimated. The higher the value of the $\mathrm{Q} 1 / \mathrm{Q} 3$ ratio, the lower the income disparity between regions.

Statistical interpretation of these data prompts two general conclusions: first, the baseline situation in 2000 as regards this indicator was quite diversified and ranged from about $82 \%$ (DE) to about 60\% (IT). In a period of 15 years, mainly after 2008, a decline in this measure can be observed in countries such as Germany, France, Spain, and Poland, and a slight increase - in Italy and the UK. In economic terms, these data confirm the increase in regional inequalities in most countries, even if the richest regions are excluded. Based on the conducted study, it seems that the tipping point for the increase in disparities was the 2008 financial crisis.

\section{Conclusion}

The article attempted to assess the direction of changes in income inequality at regional level in large European economies, using the classic measure of coefficient of variation and by estimating the empirical distribution of regional 
TABle 5. Selected MEASures desCribING DIVERSIFICATION OF REGIONAL GDP PER CAPITA [DATA IN EUR ACCORDING TO PPS $(2015=100)]$

\begin{tabular}{|c|c|c|c|c|c|}
\hline Country & Measure & 2000 & 2004 & 2008 & 2015 \\
\hline \multirow{2}{*}{ DE } & $\min / \max$ & $34,56 \%$ & $34,95 \%$ & $37,29 \%$ & $40,34 \%$ \\
\hline & $\mathrm{Q} 1 / \mathrm{Q} 3$ & $81,95 \%$ & $82,67 \%$ & $79,95 \%$ & $77,46 \%$ \\
\hline \multirow{2}{*}{ FR } & $\min / \max$ & $11,17 \%$ & $12,96 \%$ & $15,35 \%$ & $17,88 \%$ \\
\hline & Q1/Q3 & $86,23 \%$ & $87,67 \%$ & $88,30 \%$ & $86,79 \%$ \\
\hline \multirow{2}{*}{ IT } & $\min / \max$ & $43,56 \%$ & $45,37 \%$ & $45,50 \%$ & $40,33 \%$ \\
\hline & Q1/Q3 & $60,42 \%$ & $60,87 \%$ & $61,42 \%$ & $63,21 \%$ \\
\hline \multirow{2}{*}{ ES } & $\min / \max$ & $47,43 \%$ & $49,66 \%$ & $51,71 \%$ & $50,28 \%$ \\
\hline & $\mathrm{Q} 1 / \mathrm{Q} 3$ & $71,66 \%$ & $77,10 \%$ & $78,18 \%$ & $74,25 \%$ \\
\hline \multirow{2}{*}{ PL } & $\min / \max$ & $46,85 \%$ & $47,06 \%$ & $46,61 \%$ & $43,04 \%$ \\
\hline & Q1/Q3 & $78,23 \%$ & $78,97 \%$ & $81,83 \%$ & $73,45 \%$ \\
\hline \multirow{2}{*}{ UK } & $\min / \max$ & $14,03 \%$ & $14,75 \%$ & $12,94 \%$ & $11,70 \%$ \\
\hline & $\mathrm{Q} 1 / \mathrm{Q} 3$ & $76,38 \%$ & $76,72 \%$ & $77,24 \%$ & $78,87 \%$ \\
\hline
\end{tabular}

Source: own calculations based on Eurostat database (https://ec.europa.eu/eurostat/data/database).

incomes in a period from 2000 to 2015. In particular, the analysis included two events which could potentially have been relevant to the development of regional inequalities.

The identified regional distributions of income in the six economies examined were classified into three types. The first distribution is close to normal with very few so-called leading regions, observed mainly in Germany and partly in Spain. The second distribution is bimodal with two modes composed of a close-to-even number of regions, as observed in Italy. The third distribution is bimodal with a very strong capital region, or regions, and distribution for the other regions close to normal, as observed in the UK, France, and Poland. It should be noted that these three models might be linked to the regional policy of the individual countries, which may be more decentralized or on the other hand may be more focused on the sustainable development of the entire country, including regions. The evolution of regional distribution of income may also include an increasingly controversial system of financial equalization between regions.

Two time points, 2004 and 2008, were selected to determine the role of two events in the evolution of income distribution in large European economies. In the period between historically the largest accession to the EU until 2007, the level of inequalities remained rather stable in each of the countries, while 
recovery after the financial crisis was, in most cases, faster in the relatively richer regions, thus deepening the pre-existing disparities.

An additional factor that could have had an impact on income distribution in the years 2000-2015 was cohesion policy. Cohesion policy, aimed at eliminating regional inequalities, applied (of the countries under examination) mainly to Poland and Spain. Although in the initial period it did facilitate the reduction of inequalities in both countries, it was no longer an effective antidote for the increasing disparities during recovery after the crisis. This was particularly visible in Polish economy, where all regions received support and yet regional differences grew markedly. The above observations lead to the conclusion that a well-thought-out and effective internal economic policy seems to be of key importance in the fight against regional inequalities, with Germany and partly Spain as prime examples. On the other end of the spectrum are the UK and France, where regional differences are evident and, moreover, seem deeply rooted.

\section{REFERENCES}

Acemoglu, Daron (2011): Thoughts on Inequality and the Financial Crisis. Presentation at the American Economic Association Annual Meeting, Denver, Colorado, 7 January.

Antoniewicz, M., Bartkiewicz, P., Matejczuk, A., Kalinowski, H., Ośka, M., Regulski, A., \& Zawistowski, J. (2017): Jak państwa UE-15 korzystają z realizacji polityki spójności w krajach Grupy Wyszechradzkiej.

Claessens, S., \& Perotti, E. (2007): Finance and Inequality: Channels and Evidence. Journal of Comparative Economics, 35(4), 748-773.

Dabla-Norris, E., Kochhar, K., Suphaphiphat, N., Ricka, F., \& Tsounta, E. (2015): Causes and Consequences of Income Inequality: A Global Perspective, Staff Discussion Notes, 15(13).

Diez-Minguela, A., Martinez-Galarraga, J., \& Tirado-Fabregat, D. A. (2018): Regional Inequality in Spain. Regional Inequality in Spain, Palgrave Macmillan.

Epanechnikov, V. a. (1969): Nonparametric Estimation of a Multidimensional Probability Density, Teor, Veroyatnost i Primenen, 14(1), 156-161.

Eurostat (2018): Eurostat Regional Yearbook 2018 edition, Available at: https://ec.europa.eu/eurostat/documents/321 7494/9210140/KS-HA-18001 -EN-N.pdf/655a00cc-6789-4b0c-9d6d-eda24d412188.

Eurostat (2019): Eurostat Database, Available at: https://ec.europa.eu/eurostat/ data/database (accessed 06.06.2019).

Filauro, S. (2018): The EU-wide Income Distribution: Inequality Levels and Decompositions, Brussels: Publications Office of the European Union.

Galor, O., \& Moav, O. (2004): From Physical to Human Capital Accumulation: Inequality and the Process of Development, The Review of Economic Studies, 71(4), 1001-1026. 
Gradín, C. (2016): Why is Income Inequality so High in Spain? In L. Cappellari, S. W. Polachek, \& K. Tatsiramos (Eds.), Income Inequality Around the World (Vol. 44, pp. 109-177), Emerald Group Publishing Limited.

Heidenreich, N.-B., Schindler, A., \& Sperlich, S. (2010): Bandwidth Selection Methods for Kernel Density Estimation - A Review of Performance, available at SSRN.

Kołodko, G. (1993): Kwadratura pięciokąta.Od załamania gospodarczego do trwatego wzrostu. Warszawa: Poltex.

Maqueda, A. (2018): Spain Dogged by Inequality Despite Employment Boost. Retrieved March 26, 2019, from https://elpais.com/elpais/2018/05/16/ inenglish/1526457424_200147.html.

OECD. (2014): Income Inequality update Rising inequality: youth and poor fall further behind.

Quah, D. (1993): Galton's Fallacy and Tests of the Convergence Hypothesis, The Scandinavian Journal of Economics, 95(4), 427.

Sala-i-Martin, X. (2006): The World Distribution of Income: Falling Poverty and ... Convergence, Period. The Quarterly Journal of Economics, 121 (2), $351-397$.

Villar Rubio, E., Rubio, Q., Manuel, J., \& Molina Moreno, V. (2015): Convergence Analysis of Environmental Fiscal Pressure across EU-15 Countries. Energy \& Environment, 26(5), 789-802.

Wilkinson, R., \& Pickett, K. (2009): The Spirit Level: Why More Equal Societies Almost Always Do Better. London: Allen Lane.

Wójcik, P. (2004): Konwergencja regionów Polski w latach 1990-2001, Gospodarka Narodowa, 11-12, 69-86.

Wójcik, P. (2016): Estymacja jądrowa w badaniach regionalnej konwergencji. Wiadomości Statystyczne, 10(665), 7-21.

Wroński, M. (2018): Niższa produktywność pracy spowalnia wzrost płac w krajach OECD.

Zambom, A. Z., \& Dias, R. (2013): A Review of Kernel Density Estimation with Applications to Econometrics, International Econometric Review (IER), 5(1), 20-42. 

SECCIŌN DIVULGACIŌN, REVISIŌN Y ENSAYO 
